\title{
MULTI-CRITERIA DECISION MATRIX APPROACH FOR SUPPLIER EVALUATION IN MICRO AND SMALL ORGANISATIONS
}

\author{
DOI: 10.12776/QIP.V17I1.185
}

\author{
MARIA MADORANOVA, MATUS HORVATH
}

\section{INTRODUCTION}

A quality management system and its supply chain management are based on maintaining long-term partnerships with suppliers, with a focus on their reliability. Therefore the evaluation of suppliers is a necessary recurring task. The supplier evaluation problem has been studied extensively. Various decision making approaches have been proposed to tackle the problem. The reliability of a supplier cannot be based just on one criteria, therefore multi-criteria decision making approaches for supplier selection have been proposed, such as the analytic hierarchy process (AHP), analytic network process (ANP), case-based reasoning (CBR), data envelopment analysis (DEA), fuzzy set theory, genetic algorithm (GA), mathematical programming, simple multi-attribute rating technique (SMART), and their hybrids (Ho, et al., 2010). Many of these approaches show their capability, but from the view point of demands for software or information systems modification for micro ad small sized companies are too expansive. For the definition of micro and small sized companies we used the definition of the European Commission. Micro organisation is defined as organisation with 10 or fewer employees and turnover equal or less as 2,000,000 €. Small organisation is defined as organisation with 50 or fewer employees and turnover equal or less as 10,000,000 €. (European Commission, 2003) Therefore, these organisations do not perform a supplier evaluation or use just subjective procedures that do not attain the objectives of the process. The aim of the paper is present a supplier evaluation approach with Multi-Criteria Decision Matrix (MCDM) method with use of software tool created in spread sheets generator Microsoft Excel.

The paper consists of two sections. The first section deals with a case study of a supplier evaluation using multi-criteria decision matrix applied in small sized organisation. The approach takes into account the mentioned specific conditions of micro and small sized organisations. Based on the experience from the application of this approach, we introduce an extension with a supplier 
signification measure for the organisation. The concept of the extended approach is dealt with in the second section of this paper.

\section{CASE STUDY: SUPPLIER EVALUATION USING A DECISION- MAKING MATRIX IN SMALL SIZED ORGANISATION}

\subsection{Organisation specification}

The company is a leading supplier of materials and technologies for advertisement production in the Czech Republic and Slovakia. The organisation headquarters is based in Prague. In Slovakia the organisation has two offices. That is relevant from the view point of supplier evaluation, as each office has independent orders and maintains its supply chain. Therefore, supplier evaluations are performed at each office. The application of the approach was conducted in the Kosice office. The organisation and its offices do not use any type of internal information system. Most tasks are performed with the use of spread sheet application and word processor application. Also for these reasons the organisation didn't perform supplier evaluation. The issue of supplier reliability influences the organisation processes, and therefore customer satisfaction. Repeated problems related to supplier reliability were quality or delay of supply. The approach was applied for six selected suppliers.

\subsection{Decision making matrix application}

As the supplier evaluation approach we chose the Multi-Criteria Decision Matrix (MCDM). According to (Gallego, 2011:46) "decision-matrix approach, also Pugh Concept Selection, is a quantitative technique which was proposed by Pugh in 1990. It consists of establishing a set of criteria upon which the potential options can be decomposed, scored and summed to gain a total score which can then be ranked. The criteria are not weighted to allow a quick selection process". The approach is based on a qualitative evaluation in which design concepts are compared to a reference design concept. Our concept consists from two dimensions. Each axis is a vector of selected criterion of reliability of organisation suppliers. We used two basic criteria quality of supplies $Q$ and timeliness of delivery $T$. The criteria were calculated according to the formulas (1), (2) (Nenadál, 2006:194).

$$
\begin{aligned}
Q & =\frac{\text { number of conforming items in the delivery }}{\text { total number of items in the delivery }} \\
T & =\frac{\text { number of ontime delivered items from the delivery }}{\text { total number of items in the delivery }}
\end{aligned}
$$

As another option for calculation of $Q$ criteria can be used (3): 


$$
Q=\frac{\text { number of conforming items in the delivery }}{\text { agreed or planed number of conforming items in the delivery }}
$$

In a pre-agreed cases, it is appropriate to use ISO 2859-10:2006 which provides acceptance sampling by attributes and guidance on the selection of the appropriate inspection system for use in a particular situation.

As the delivery parameter, we choose a time frame of one month. The calculation of these criteria is based on three values. Table 1 includes the values for each supplier of the office.

Table 1 - Values for supplier evaluation from the Kosice office (Mad'oranová, 2013)

\begin{tabular}{|c|c|c|c|c|c|c|c|}
\hline Suppliers & $\begin{array}{c}\text { Ordered } \\
\text { number of } \\
\text { items }\end{array}$ & $\begin{array}{c}\text { Number of } \\
\text { on-time } \\
\text { delivered } \\
\text { items }\end{array}$ & $\begin{array}{c}\text { Number of } \\
\text { delayed } \\
\text { items }\end{array}$ & $\begin{array}{c}\text { Number of } \\
\text { conforming } \\
\text { items }\end{array}$ & $\begin{array}{c}\text { Number of } \\
\text { nonconforming } \\
\text { items }\end{array}$ & $\boldsymbol{Q}$ & $\boldsymbol{T}$ \\
\hline A & 16 & 15 & 1 & 12 & 3 & 0,80 & 0,94 \\
\hline B & 14 & 14 & 0 & 14 & 0 & 1,00 & 1,00 \\
\hline C & 4 & 3 & 1 & 3 & 0 & 1,00 & 0,75 \\
\hline D & 27 & 20 & 7 & 18 & 2 & 0,90 & 0,74 \\
\hline E & 155 & 155 & 3 & 146 & 9 & 0,94 & 1,00 \\
\hline F & 81 & 68 & 13 & 68 & 0 & 1,00 & 0,84 \\
\hline
\end{tabular}

\subsection{Design of the decision matrix}

The decision matrix is divided into four quadrants. For the division, we need to choose an acceptable limit separate for each criterion. This acceptable limit (AL) in some literature is referred to as Acceptable Quality Limit - AQL (Zgodavova, et al., 2002:4.57). According to (Nenadál, 2006:194) criteria divide the matrix into:

Quadrant 1 (Q1) - the supplier is sufficiently reliable from the view point of the timeliness of delivery $T$, but not sufficiently reliable from the view point of quality of supplies $Q$.

Quadrant $2(\mathrm{Q} 2)$ - the supplier is sufficiently reliable from the view point of the timeliness of delivery $T$ and quality of supplies $Q$.

Quadrant $3(\mathrm{Q} 3)$ - the supplier is not sufficiently reliable from the view point of the timeliness of delivery $T$ and quality of supplies $Q$.

Quadrant 4 (Q4) - the supplier is sufficiently reliable from the view point of the quality of supplies $Q$, but not sufficiently reliable from the view point of the timeliness of delivery $T$ 
Based on the discussion with organisation office staff, we selected the acceptable level of 0.85 for both criteria. This means that the supplier delivery (in our case, each month) has to reach $85 \%$ of conforming items and $85 \%$ on-time delivered items to be included in the quadrant with the best rating (quadrant II). From the values in table 1 the decision matrix on Figure 1 was created.

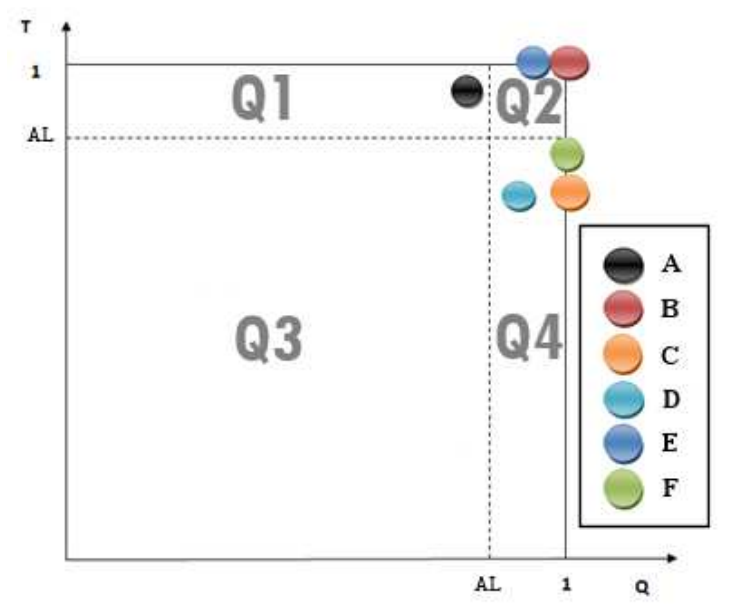

Figure 1 - Decision matrix with supplier rating (Mad'oranová, 2012)

An organisation, according to continual improvement, may gradually increase acceptable limits for criteria. In this way, an organization can gradually increase the reliability of its suppliers.

\subsection{Proposed software support}

Supplier evaluation is a repetitive process. Therefore, we decided to support this process in the organisation with a software tool. The tool was created in Microsoft Excel. With the help of predefined formulas this tool can calculate the values of $Q$ and $T$ criteria, and determine the quadrant of the supplier. The tool contains help texts for the user that describes quadrants from the perspective of future steps for the organisation. 


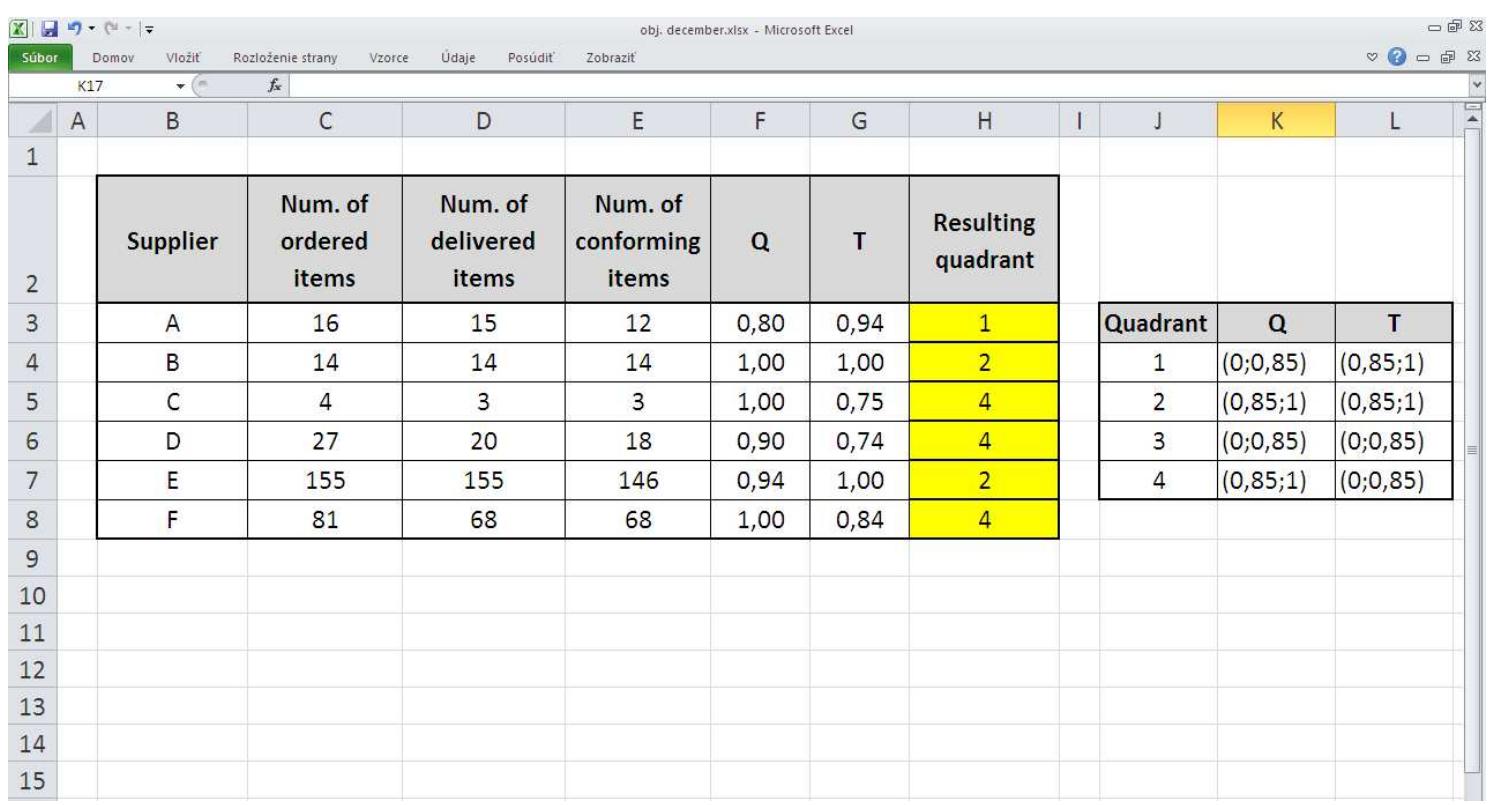

Figure 2 - Screenshot of the tool with shown formula (Mad'oranová, 2012)

\subsection{Proposed actions}

From the results the following actions can be recommended. Supplier A is in quadrant 1 . This means that the supplier has problems with reliability from the view point of quality. We recommend focusing on methods such as output inspection at supplier and stricter conditions for delivery. Suppliers C, D and F have problems with timeliness of delivery (quadrant 4). For these suppliers, the just in time method cannot be used. As a short-term action, we recommend increasing stocks of items from these suppliers. As a long-term action, we recommend focusing on on-time delivery, with better conditions for delivery or change the supplier for these items. The supplier E and B achieve results that range it in quadrant 2 . This is the quadrant for sufficient reliability but within this quadrant suppliers achieve different values of $Q$ and $T$. The supplier E has gaps in the quality of the can delivery but $100 \%$ timeliness of delivery. The best reliability was achieved by supplier B. Its $100 \%$ timeliness of delivery and $100 \%$ quality of delivery makes it suitable as a model for other suppliers.

\section{DISCUSSION AND FUTURE WORK}

The presented approach and followed case study is focused on supplier evaluation for micro and small organisation. Therefore the approach was as much as possible constructed as undemanding for time and cost. The approach allows the organisation to set its own criteria and acceptance limit for supplier reliability. With the software tool that is used in common application (Microsoft Excel) this approach can be used in practically every organisation without the long training of users. In the long-term view, an organisation with the regular repeating of the process of supplier evaluation can obtain reliable data about 
trends in supplier reliability. This is a reasonable basis for reviewing contracts and cooperation with suppliers.

The presented approach can be extended in two ways. The calculation of supplier reliability can be based on more criteria than two. Expanding the number of criteria can refine supplier reliability, and it will expand the number of dimensions of the decision matrix and the number of quadrants. Therefore, the graphical expression of the decision matrix can be more difficult, but with the use of the presented software tool this is not a problem. New criterion for supplier reliability for example can be satisfaction of the organisation with supplier cooperation. It can be expressed by the proportion of accepted complaints. Other criteria and measures can be found, for example, in the appendix of the literature review paper (Ho, et al., 2010) and (Zgodavova, 2003:59-57).

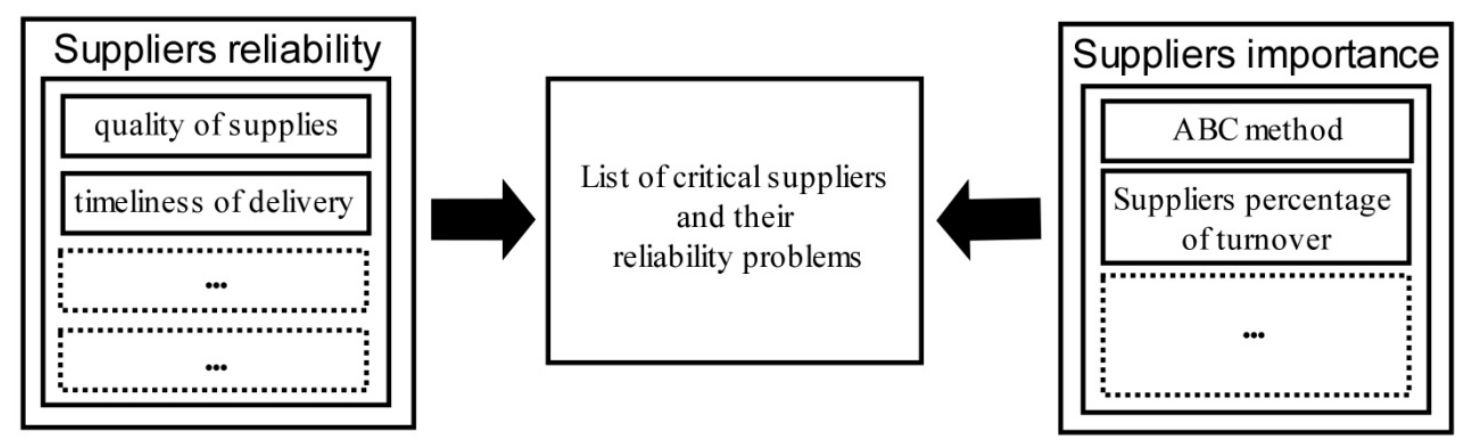

Figure 3 - Concept of the extended approach (own conception)

During the approach application in the organisation, we noticed another possibility to extend the presented approach. The presented approach does not consider the importance of the supplier from the view of the importance of the supplier for the organisation. It may cause that the organisation will focus on the supplier that does not meet the acceptable limits, but is from the view of the organisation not an important supplier (in terms of turnover or supplied items) and does not give attention to an important supplier with one fulfilled acceptable limit. The same effort may in this case result in a different impact on the overall supplier reliability of the organization. For the importance of supplier expression, the ABC method can be used or the proportion of the supplier's items of organisation turnover. With the linking of supplier reliability and its importance for the organisation, we can focus on critical suppliers and their problems. This extension can save resources, with a better focus on serious problems in the supply chain of the organisation. In our future work, we want to focus on the development of the approach towards the presented extensions, and apply this extended approach in real-world micro and small organizations. 


\section{REFERENCES}

Dai, L., Liu, Y, Zhang, Z., 2008. In: Supplier Selection with Multiple Criteria under Fuzzy Environment, Wireless Communications. In Networking and Mobile Computing WiCOM'08, 12-14 Oct. 2008 Dalian, DOI: 10.1109/WiCom.2008.1652.

European commission, 2003. 2003/361/EC. Commission Recommendation of 6 May 2003 concerning the definition of micro, small and medium-sized enterprises. Brussels. 2003

Gallego, L. V. 2011. Review of existing methods, models and tools for supplier evaluation.Master thesis. Institute of technology, Linköpings Universitet Sweden, 46 pp.

Ho W., Xu X., Dey K. P., 2010. Multi-criteria decision making approaches for supplier evaluation and selection: A literature review, European Journal of Operational Research, Volume 202, Issue 1, pp. 16-24, ISSN 0377-2217, http://dx.doi.org/10.1016/j.ejor.2009.05.009.

International Standard Organisation, 2006. ISO 2859-10:2006 Sampling procedures for inspection by attributes - Part 10: Introduction to the ISO 2859 series of standards for sampling for inspection by attributes.

Jajimoggala, S., Rao, V.V.S.K., Beela, S., 2011. Supplier evaluation using hybrid multiple criteria decision making approach, International Journal of Applied Decision Sciences, Volume 4, Issue 3, pp. 260-279.

Kiauta, M., 2012. Idea of quality versus idea of excellence, Quality Innovation Prosperity, Volume 16, Issue 2, pp. 103-114.

Mad'oranová, M. 2012. Návrh a aplikácia hodnotenia dodávatelov v nevýrobnej organizácii/Proposal and application of evaluation of vendors in the nonmanufacturing organization, Diploma thesis. Košice. TU SJF.

Mad'oranová, M. 2013. Hodnotenie dodávatel'ov pomocou rozhodovacej matice v organizácii: prípadová štúdia /Suppliers evaluation with help of decision matrix in the organisation: case study, In: TU Košice, Metalurgia Junior 2013 : Zborník prednášok z konferencie, Košice Slovakia, 22. - 23. May 2013. Košice. TU Košice, 2013. p. 29-32, ISBN 978-80-553-1429-7.

Nenadál, J., 2006. Management partnerství a dodávateli - Nové perspektívy firemního nakupováni, Management Press, CZ, p. 194.

Zgodavova, K., Linczényi, A., Nováková, R., Slimák, I., 2002. Profesionál kvality/Quality for Professionals, Chaper 4.57. Technická univerzita v Košiciach, Košice, Slovak Republic.

Zgodavová, K., 2003. K niektorým otázkam iracionálnosti finančného rozhodovania $\mathrm{v}$ manațérstve kvality / Some issues of irrationality of financial decision-making in quality management, E+M Economics \& Management, 4/2003 pp. 59-70. 


\section{ABOUT THE AUTHORS}

Maria Madoranova, Ing. - PhD. student, Technical University of Košice, email: maria.madoranova@tuke.sk, Letna 9, 04200 Košice, Slovakia, (PhD advisor: Kristina Zgodavova, Prof., PhD., Technical University of Košice, email: kristina.zgodavova@tuke.sk, Letna 9, 04200 Košice, Slovak Republic.

Matus Horvath, Ing. - PhD. student, Technical University of Košice, e-mail: matus.horvath@tuke.sk, Letna 9, 04200 Košice, Slovakia, (PhD advisor: Edita Virčíková, Prof., PhD., Technical University of Košice, e-mail: edita.vircikova@tuke.sk, Letna 9, 04200 Košice, Slovakia 